\title{
Transition Analysis of Budgetary Allocation for Projects on Hydrogen-Related Technologies in Japan
}

\author{
Kazuhiro Hikima ${ }^{1,2,3}$, Masaharu Tsujimoto ${ }^{2}$, Mizutomo Takeuchi ${ }^{2}$ and Yuya Kajikawa ${ }^{2, *}$ \\ 1 Department of Chemical Science and Engineering, School of Materials and Chemical Technology, \\ Tokyo Institute of Technology, 4259 Nagatsuta, Midori-ku, Yokohama-shi, Kanagawa 226-8502, Japan; \\ hikima@ee.tut.ac.jp \\ 2 Department of Innovation Science, School of Environment and Society, Tokyo Institute of Technology, \\ 3-3-6 Shibaura, Minato-ku, Tokyo 108-0023, Japan; tsujimoto.m.ac@m.titech.ac.jp (M.T.); \\ takeuchi@mot.titech.ac.jp (M.T.) \\ 3 Department of Electrical and Electronic Information Engineering, Toyohashi University of Technology, \\ 1-1 Hibarigaoka, Tempaku-cho, Toyohashi-shi, Aichi 441-8580, Japan \\ * Correspondence: kajikawa@mot.titech.ac.jp; Tel.: +81-3-3454-8754
}

Received: 22 August 2020; Accepted: 12 October 2020; Published: 15 October 2020

\begin{abstract}
Hydrogen technologies are promising candidates of new energy technologies for electric power load smoothing. However, regardless of long-term public investment, hydrogen economy has not been realized. In Japan, the National Research and Development Institute of New Energy and Industrial Technology Development Organization (NEDO), a public research-funding agency, has invested more than 200 billion yen in the technical development of hydrogen-related technologies. However, hydrogen technologies such as fuel cell vehicles (FCVs) have not been disseminated yet. Continuous and strategic research and development $(\mathrm{R} \& \mathrm{D})$ are needed, but there is a lack of expertise in this field. In this study, the transition of the budgetary allocations by NEDO were analyzed by classifying NEDO projects along the hydrogen supply chain and research stage. We found a different R\&D focus in different periods. From 2004 to 2007, empirical research on fuel cells increased with the majority of research focusing on standardization. From 2008 to 2011, investment in basic research of fuel cells increased again, the research for verification of fuel cells continued, and no allocation for research on hydrogen production was confirmed. Thereafter, the investment trend did not change until around 2013, when practical application of household fuel cells (ENE-FARM) started selling in 2009, in terms of hydrogen supply chain. Hydrogen economy requires a different hydrogen supply infrastructure, that is, an existing infrastructure of city gas for ENE-FARM and a dedicated infrastructure for FCVs (e.g., hydrogen stations). We discussed the possibility that structural inertia could prevent the transition to investing more in hydrogen infrastructure from hydrogen utilization technology. This work has significant implications for designing national research projects to realize hydrogen economy.
\end{abstract}

Keywords: hydrogen society; national projects; grant distribution; structural inertia

\section{Introduction}

The adoption of renewable energy, such as solar and wind power, has progressed rapidly in recent years; for example, the system cost of solar power decreased while adoption increased rapidly-approximately tenfold from 2010 to 2016 [1]. However, renewable energy has unstable output because renewable energies depend on weather and daylight conditions. To cope with the volume growth of renewable energy, it is vital to introduce and develop technologies for electric power load smoothing. These technologies typically focus on energy storage and/or energy conversion. 
Hydrogen-related technologies such as hydrogen production, storage, transport, and fuel cells are one of the clusters of technologies for electric power load smoothing. Hydrogen can be produced from the electricity surplus of renewable energy production as $\mathrm{CO}_{2}$-free energy sources and used later for fuel cell operation [2-4]. Thus, hydrogen is one of the promising candidates for smoothing the electric power load [5].

The role of hydrogen is not limited to energy storage for renewable energy systems described above. Hydrogen economy has been proposed as a vision where hydrogen is used as the energy carrier not only in transportation but also in the power generation sector [6-9]. However, it is not easy to realize hydrogen economy, and transition from the current energy system to hydrogen economy has been investigated in the previous literature [10-14]. Hydrogen economy has faced the cycle of hope and hype [15] among diverse stakeholders having different expectations [16].

There are several issues regarding dissemination of hydrogen-related technologies, such as household fuel cell and fuel cell vehicles (FCVs), which include cost [17-20], social awareness, perception and acceptance [21], lack of suppliers, infrastructure, and customers in a two-sided market [22,23]. These factors are interrelated, and some will be resolved after a wide range of disseminations. For example, in Japan, fuel cells started sales for home use in 2009 [24]. Since then, fuel cell price has gradually decreased. Market dissemination has been growing steadily, surpassing 10 million units in 2014. Certainly, the situation is different between fuel cells for home and FCVs. Another report discusses a survey about the widespread status of FCVs [25]. One of these vehicles, MIRAI, started selling in 2014 [26]. Although the number of FCVs sold reached 2000 in 2017, sales were considered to be sluggish when compared with the sales of household fuel cells [4]. It is clear that long-term commitment is still needed to realize hydrogen economy [3], and technological advancement is expected to play a key role.

The aim of this paper is to investigate the R\&D trajectory in Japan and compare it with the trend of main actors in the field to drive implications for R\&D planning and management based on observation. Japan has been a leading country in technological development for hydrogen technologies. We investigated the number of patents related to fuel cell technology. In Japan, there were 48,672 patents related to fuel cell technologies from 1993 to 2020. This is approximately three times the number of patents in the United States $(16,752)$ and China $(16,689)[27]$, and therefore worthy of investigation. The methodology and discussion about the number of patents is covered later. We analyze resource allocation patterns among projects by the National Research and Development Institute of New Energy and Industrial Technology Development Organization (NEDO, Kawasaki-shi, Kanagawa, Japan). NEDO is one of the public research-funding agencies in Japan; it has invested more than 200 billion yen in the technical development of hydrogen-related technologies, such as fuel cells, after 1993 [28-31].

Since NEDO has been investing heavily in research on hydrogen-related technologies, we inferred that NEDO projects played a key role in technological development and dissemination of technologies. However, we found little to no research on the analysis of budget allocations of the largest research funders (in our case, NEDO). Here, we analyzed NEDO-funded projects on hydrogen-related technologies to clarify the background issues related to the current penetration rate of household fuel cells and FCVs. The time-series changes of research funds were investigated in terms of the budget allocations by classifying along the hydrogen supply chain and research stage.

The rest of the paper is organized as follows. In Section 2, we discuss the methodology. Section 3 presents the results. Section 4 presents the discussion. Finally, Section 5 presents the conclusion.

\section{Methodology}

\subsection{Data}

The NEDO projects related to hydrogen technology such as fuel cells and FCVs were analyzed by using public data available on the NEDO website [32]. The information was extracted by searching for the keywords, "fuel cell" and "hydrogen." The survey period was between 1993 and 2016, because one 
of largest research projects on hydrogen technologies at NEDO, the World Energy Network (WE-NET), started in 1993. Budget information was extracted from documents of the basic plan for each project, implementation policies, and project ledgers for each year. There were 30 hydrogen-related technology NEDO projects in the survey period. The total budget for each project was calculated by adding up the project allocation in the budgets in each year. The NEDO projects associated with hydrogen-related technology were classified along the hydrogen supply chain and research stage based on the basic plan, yearly plan, and project ledger.

We also utilized other information resources to supplement the analysis on the NEDO projects. To investigate the backgrounds of resource allocation change, we referred to the webpage of the Ministry of Economy, Trade and Industry (METI), the Japanese Cabinet Office, and the Japanese Prime Minister's Office for identified keywords [33-35]. It was impossible to access information prior to 2000, so the website for the achieving project (WARP) was used to go through archived information [36]. The survey period was the same as that of the NEDO project (1993-2016). The total subsidy related to fuel cells by the METI was also analyzed. The METI website was searched for the keywords, "fuel cell," and "hydrogen" [33].

Industrial policy can be influenced by industrial actors. Therefore, we searched for major industrial actors from the following database. We use Nikkei Information on Firms' Activities available from Nikkei Value Search for the actor analysis. This is a database containing timely disclosure information and press releases. Nikkei Shimbun and Nikkei Sangyo Shimbun are classified in accordance with the definitions shown in Supplementary Materials Table S1. This table contains, therefore, the firms' cession information. Since 1997, researchers at Nikkei Research have been carrying out data updates 30 to 50 times a day. As of August 2017, the database contained nearly 200,000 pieces of datum. We searched the database using the keywords "hydrogen" and "fuel cell." In Nikkei Information on Firms' Activities, the researcher must input a short outline of a few hundred characters per activity and the keyword search is conducted with the activity titles and these outlines. There were 928 activities that were extracted. However, this information sometimes included noise. Next, one of the authors (MT), who worked for a major energy-related firm for an extensive period, carefully examined all activities with the use of "hydrogen" and "fuel cell" as keywords. The result showed that out of 928 activities, 501 were related to hydrogen energy. The current article analyzed the information from these 501 activities. We also investigated the website of the Council on Competitiveness-Nippon (COCN) [37]. The survey period was the same as that of the NEDO project (1993-2016).

The number of patents related to fuel cells and hydrogen-related technologies was investigated using Derwent Innovation, which collects patent data from 44 issuing authorities. An equivalent query was applied per Derwent syntax as follows: For patents related to fuel cell, "ALLD = ("FUEL CELL") AND AY $\geq(1993)$ AND AY $\leq(2020) "$, for patents related to hydrogen technology, "ALLD = (“HYDROGEN") AND AY $\geq$ (1993) AND AY $\leq$ (2020)". Patent data were retrieved on 17 September 2020.

NEDO is one of the biggest funding agencies in Japan and has played a major role in hydrogen energy development. Nonetheless, we also collected data from another funding agency, Japan Society for the Promotion of Science (JSPS, Tokyo, Japan), that focuses on basic science. We used the database of the Grant-in-Aid for Scientific Research (KAKENHI) by JSPS. The keyword search in the Scientific Research Grant Program database extracted research projects related to hydrogen and fuel cells [38]. The keywords used to search in the KAKENHI database corresponding to each stage of the hydrogen supply chain are shown below: (1) Hydrogen production: Hydrogen production, $\mathrm{CO}_{2}$-free hydrogen, Hydrogen fuel; (2) Transport, storage, supply: Hydrogen transport, Hydrogen storage, Hydrogen fuel tank, Hydrogen container, Hydrogen station, Hydrogen infrastructure, Hydrogen supply; (3) Utilization: Fuel cell; (4) Multiple: Hydrogen society. The total research funds for each year were calculated by adding the funds for each research project in that year. It should be noted that the research status was set to "all," and the survey period was between the years of 1993 and 2016 (same as that for the NEDO project analysis). 


\subsection{Method}

We analyzed the budget allocations of NEDO by classifying along the hydrogen supply chain and research stages. On the hydrogen supply chain, we classified each project into: (1) Hydrogen production; (2) Transport, storage, and supply; (3) Utilization; and (4) Multiple. As regards the research stage, we created the following classification schemes: (A) Research, basic techniques, materials, and components; (B) Products and system development; (C) Demonstration and commercialization studies; (D) Test, evaluation methods, and standardization; and (E) Investigation research. The detailed definitions for each classification and classification scheme are listed below.

1. Hydrogen production

If the project name, title, or summary contained "hydrogen production" or words paraphrasing hydrogen production (gas utilization, $\mathrm{CO}_{2}$-free hydrogen, etc.) and the content was determined as technology related to hydrogen production, the projects were classified as "hydrogen production."

2. Transport, storage, and supply

If the project name, title, or summary contained "transport, storage, supply" or words paraphrasing transport, storage, supply (fuel tank, hydrogen container, hydrogen station, hydrogen, and infrastructure, etc.) and the content was determined as technology related to the transport, storage, and supply, the projects were classified as "transport, storage, and supply."

\section{Utilization}

If the project name, title, or summary contained "fuel cell" or "components used in the fuel cell," the projects were classified as utilization. After the initial screening, the summary in the basic plan was checked for projects other than hydrogen "utilization."

4. Multiple

The projects that fell under all the multiple processes of (1) to (3) were classified as "multiple."

Detailed definitions and classification of the research stage are as follows:

A. Research, basic techniques, materials, and components

If the project name, title, or summary contained "basic research," "reaction mechanism analysis" or words to paraphrase basic research (the fuel cell member, cell, stack, etc.) and the content was determined as research-based technologies, materials and members level, these projects were classified as "research, basic techniques, materials and components."

B. Products and system development

The products and systems development in this study are defined as FCVs, cogeneration systems, products equipped with fuel cell, and hydrogen-related products. If the project name, title, or summary contained "fuel cell products," "hydrogen-based products" or words to paraphrase the fuel cell products or hydrogen-based products (cogeneration systems, etc.) and the content was determined as products and systems development level, these projects were classified as "products and system development."

C. Demonstration and commercialization studies

If the project name, title, or summary contained "demonstration" and the content was determined as demonstration level, these projects were classified as "demonstration and commercialization studies."

D. Test, evaluation methods and standardization 
If the project name, title, or summary contained "the system (software)" or words to paraphrase the system (software) and the content was determined as test, evaluation standardization level, these projects were classified as "test, evaluation methods and standardization."

E. Investigation research

If the project name, title, or summary contained "the investigation research" or words to paraphrase the investigation research and the content was determined as investigation research, these projects were classified as "investigation research."

\section{Results}

Figure 1 illustrates the annual total budget change of NEDO hydrogen projects. Between 1999 and 2002, the total budget increased from several tens of billion yen to around 100 billion yen and 150 billion yen in 2000 and 2002, respectively. Then, it increased rapidly to 210 billion yen in 2006 . In 2009 and 2010, the total budget started dwindling and was approximately 80 billion yen in 2011 . After 2014, the total budget showed a slight increase. From these observations of the total budget change, we classified the following five phases in the funding of hydrogen technologies as follows:

- Phase 1: From 1993 to 1999 (Initial stage),

- Phase 2: From 2000 to 2003 (Expansion stage),

- Phase 3: From 2004 to 2007 (Growth stage),

- Phase 4: From 2008 to 2011 (Decline stage), and

- Phase 5: From 2012 to 2016 (Re-attention stage).

As described below, we observed different budget allocation strategies in different phases. In addition, the average budget in each stage was 13, 124, 180, 133, and 107 hundred million yen, respectively.

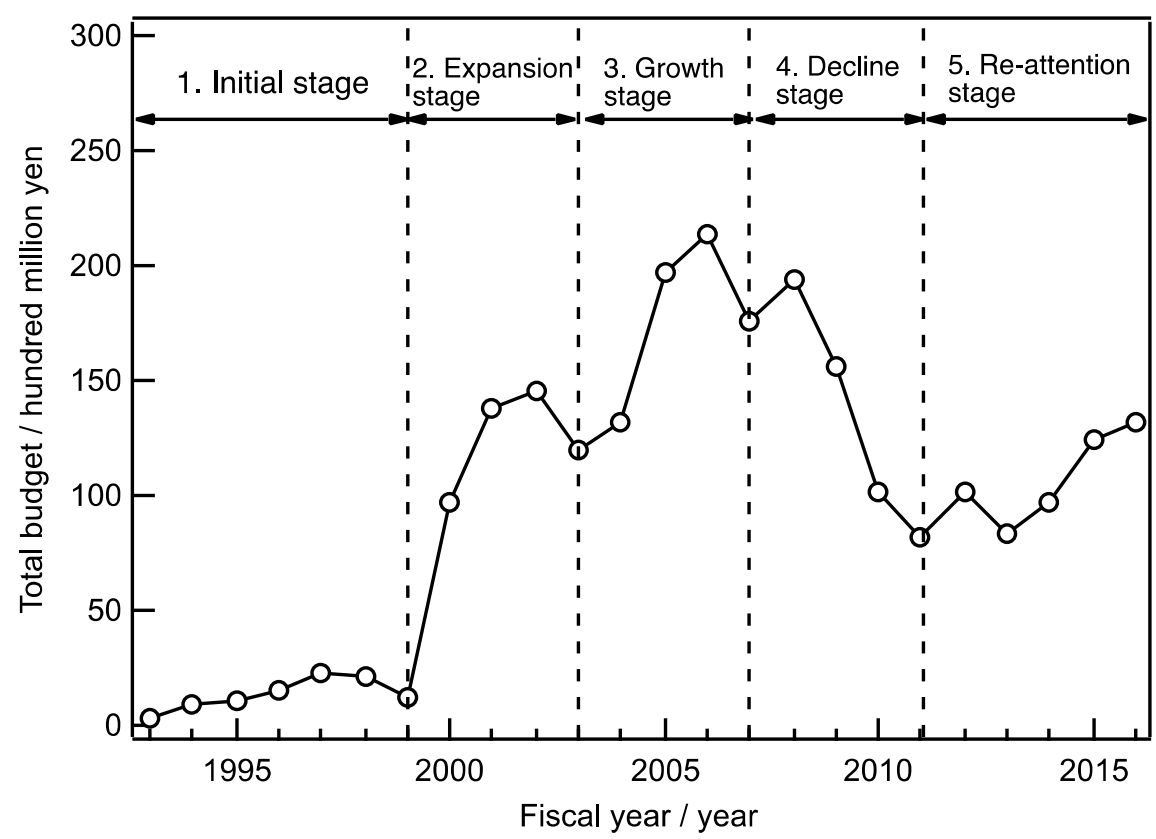

Figure 1. Transition of annual total budget and average budget for each research phase of National Research and Development Institute of New Energy and Industrial Technology Development Organization (NEDO) projects related to hydrogen technologies.

Figures 2 and 3 show the budget allocation in Phases 1-5 along the hydrogen supply chain and research stages, respectively. 
In the initial stage, the WE-NET project was undertaken, and each of the hydrogen production and storage technologies were allocated approximately $40 \%$ of the budget for the hydrogen supply chain. Furthermore, hydrogen utilization and investigation research funds were distributed at approximately $50 \%$ and $10 \%$, respectively. In contrast, the allocation of basic research funds for materials and members was $85 \%$ in terms of the research stage. Investigation research accounted for approximately $15 \%$. We found that basic research was carried out in each of the four hydrogen supply chain levels as shown in Figures 2 and 3.

Although hydrogen production and multiple projects dwindled in the expansion stage, hydrogen utilization projects rapidly increased to approximately $80 \%$ in the same phase. The main projects during the expansion period were related to molten carbonate fuel cells (MCFCs), polymer electrolyte fuel cells (PEFCs) using liquified petroleum gas (LPG), and conventional PEFCs. Thus, we see that the allocation of fuel cells (MCFCs and PEFCs) was increased in the expansion stage. In terms of the research stage, the basic research on materials and members declined. The ratio of research projects related to testing, evaluation methods, and standardization increased to approximately $30 \%$. These changes indicated that evaluation technology related to PEFCs could be the focus in the expansion stage, considering the hydrogen supply chain classification.

Although there was no drastic change in the trend of utilization at the growth stage, the distribution ratio of the storage technology projects also increased. The main projects in the growth stage were related to solid oxide fuel cells (SOFCs), portable fuel cells, and new usage of fuel cells. Here, we see that the investment targeted toward fuel cells was diversified. In terms of the research stage, empirical research increased with most research projects on standardization.

In the decline stage, the allocation was similar to the expansion stage, and focused on investment in fuel cells. The main projects were about standardization of PEFCs and research on SOFCs. Here, we see that the investment targeted toward fuel cells was uniform. There were no research projects on hydrogen production. In terms of the research stage, the investment in basic research, materials and components increased again. Furthermore, research projects for verification were continued, and no allocation for research on hydrogen production was seen.

In the re-attention stage, hydrogen production projects were again allocated funding and the allocation ratio continued to be flat at approximately $5 \%$. In contrast, hydrogen transportation, storage, supply, and hydrogen utilization allocation decreased gradually. Moreover, the distribution ratio of research and development (R\&D) for multiple projects on the supply chain increased to $50 \%$. In terms of the research stage, the distribution proportion of basic research, materials, and member level decreased rapidly to $45 \%$. Allocations for projects on products and systems products increased rapidly to approximately $25 \%$. Furthermore, an increase in hydrogen production and compositive levels was observed.

Based on Nikkei Information on Firms' Activities available from Nikkei Value Search, the hydrogen energy actor network was analyzed. The hydrogen energy actors formed a complicated network. The changes in the number of actors involved in this network are shown in Table 1. The number of actors involved was counted for each year, regardless of their position but excluding duplication. In other words, whether they were an investor or investee was not considered, but the number of actors who were involved with some activities was counted each year without duplication. We see that the change in the number of actors related to hydrogen technologies increased from 1999 to 2000. After 2000, the increase in the number of actors was almost flat and range-bound until 2011. It was followed by a rapid increase from 2011 to 2016. 


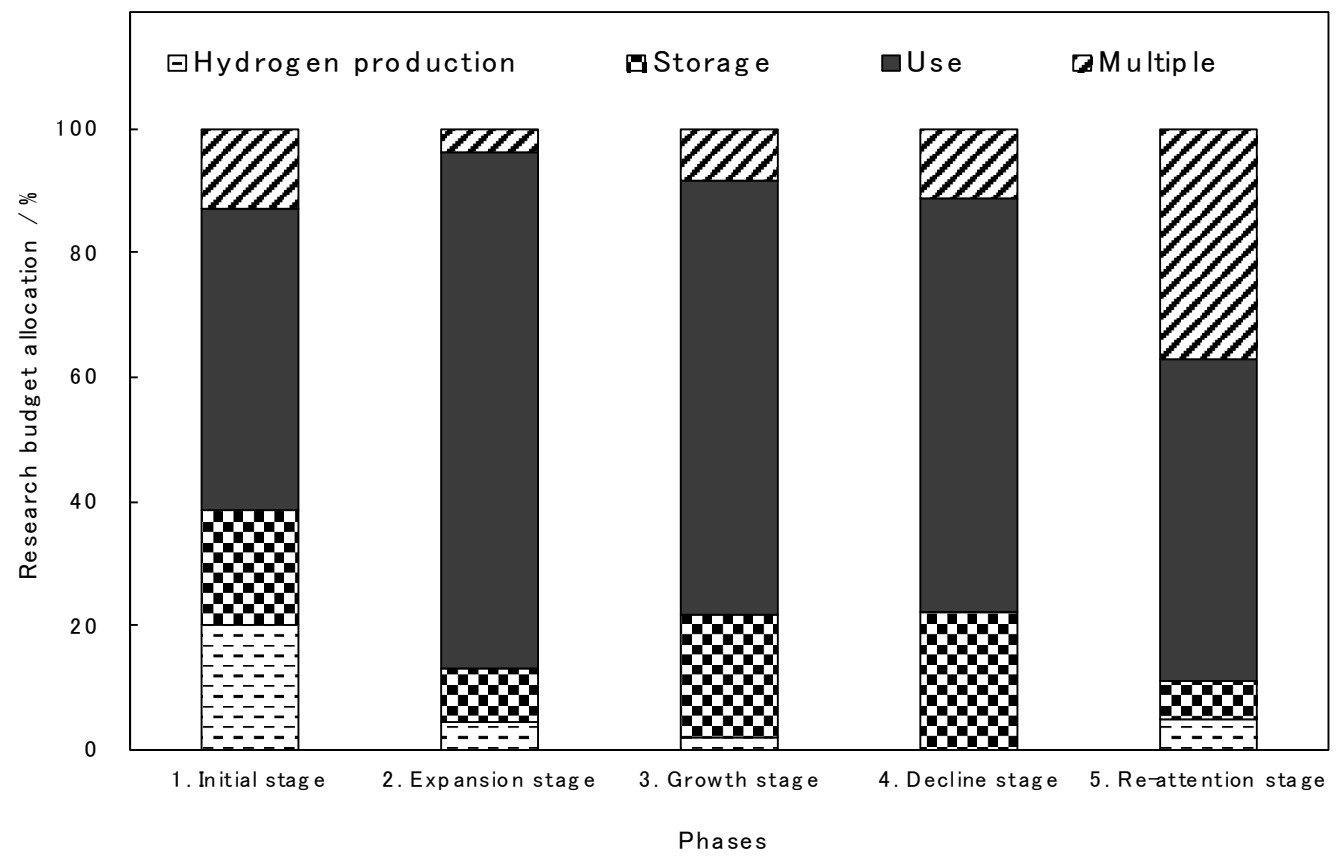

Figure 2. Transition of budgetary allocation ratio for NEDO-funded research projects on the hydrogen supply chain.

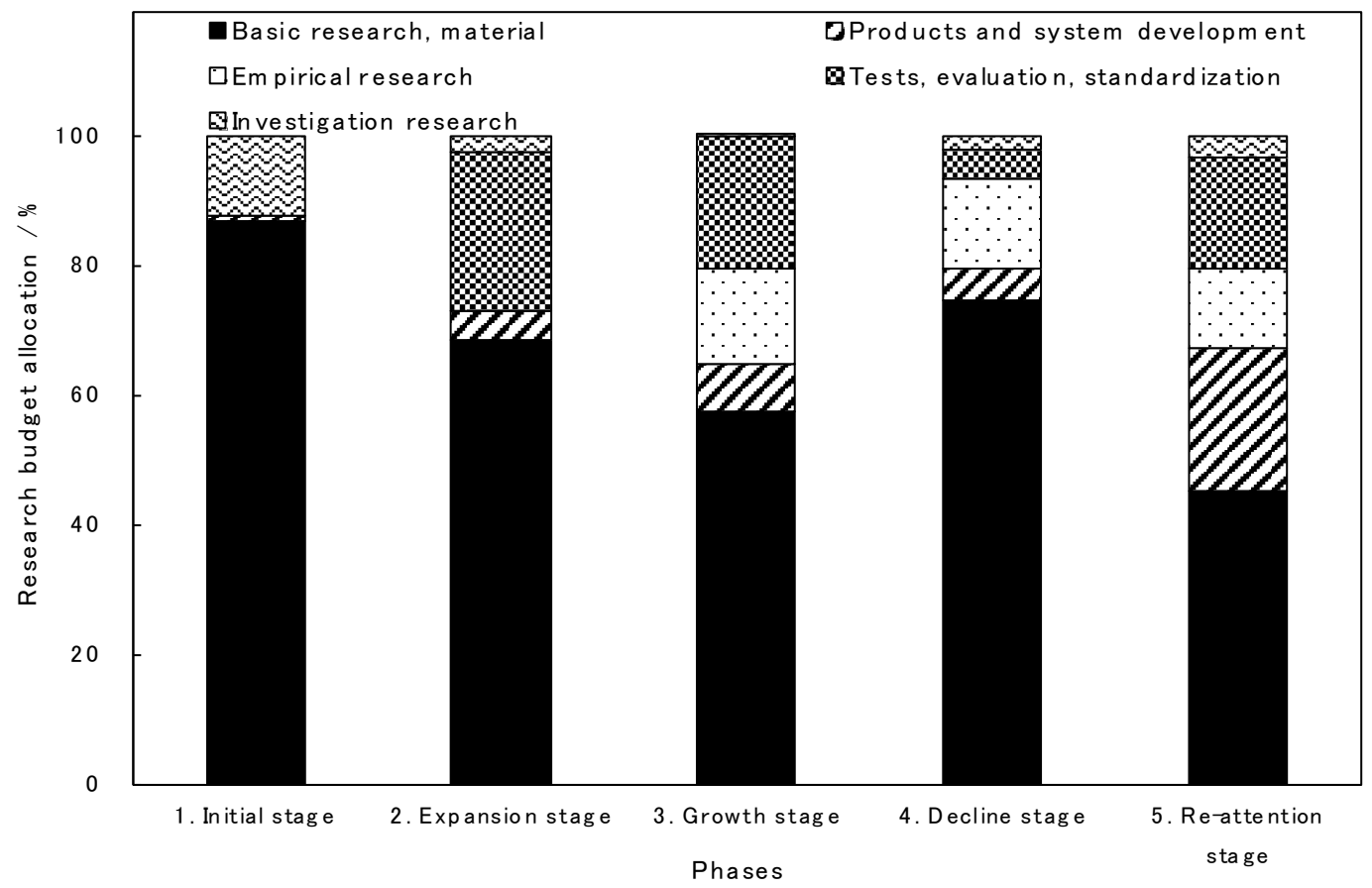

Figure 3. Transition of budgetary allocation ratio for NEDO projects by research stage for hydrogen-related technology. 
Table 1. Transitions of behaviors and actors in each stage.

\begin{tabular}{|c|c|c|c|c|c|}
\hline \multirow{2}{*}{ Behavior } & \multicolumn{5}{|c|}{ The Ratio of Behaviors (\%) } \\
\hline & $\begin{array}{l}\text { From } 1993 \text { to } 1999 \\
\text { (Initial Stage) }\end{array}$ & $\begin{array}{l}\text { From } 2000 \text { to } 2003 \\
\text { (Expansion Stage) }\end{array}$ & $\begin{array}{l}\text { From } 2004 \text { to } 2007 \\
\text { (Growth Stage) }\end{array}$ & $\begin{array}{l}\text { From } 2008 \text { to } 2011 \\
\text { (Decline Stage) }\end{array}$ & $\begin{array}{c}\text { From } 2012 \text { to } 2016 \\
\text { (Re-Attention Stage) }\end{array}$ \\
\hline Strengthening of the existing business & 42 & 39 & 41 & 68 & 48 \\
\hline Establishment of a joint venture & 25 & 12 & 8 & 1.3 & 6.4 \\
\hline Minority capital participation & 17 & 14 & 10 & 5.1 & 2.1 \\
\hline $\begin{array}{l}\text { Business collaboration such as sales, } \\
\text { technology, and production }\end{array}$ & 8 & 28 & 27 & 18 & 33 \\
\hline Reduction of the existing business & 8 & 2.6 & 0 & 1.3 & 3.1 \\
\hline Merger/business integration & 0 & 2.6 & 3 & 1.3 & 1.6 \\
\hline Cancellation or postponement of a plan & 0 & 1.3 & 4 & 0 & 0 \\
\hline Establishment of a new company & 0 & 0 & 3 & 1.3 & 2.1 \\
\hline Entry to a new business area & 0 & 0 & 2 & 0 & 1.6 \\
\hline $\begin{array}{l}\text { Acquisition of a business sector, intangible } \\
\text { fixed assets, and tangible fixed assets }\end{array}$ & 0 & 0 & 0 & 3.8 & 2.1 \\
\hline Total & 100 & 100 & 100 & 100 & 100 \\
\hline $\begin{array}{c}\text { Actors } \\
\text { (Number of Appearance }(>2))\end{array}$ & $\begin{array}{l}\text { Ebara (4), } \\
\text { Ballard Generation } \\
\text { Systems (2). }\end{array}$ & $\begin{array}{c}\text { Ebara (6), } \\
\text { Osaka gas (4), } \\
\text { Toshiba (4), } \\
\text { International Fuel Cells (4), } \\
\text { Corona (3), } \\
\text { Mitsubishi Corp (3), } \\
\text { Sumitomo Corp (3), } \\
\text { IHI (3), } \\
\text { Tokyo Gas (3), } \\
\text { Nissinbo (3). }\end{array}$ & $\begin{array}{c}\text { Nippon Oil Corporation } \\
\text { (6), } \\
\text { Ebara (3), } \\
\text { Iwatani (3), } \\
\text { Matsushita Electronic (3), } \\
\text { Air Water (3), } \\
\text { Nissan Motors (3). }\end{array}$ & $\begin{array}{c}\text { Iwatani (37), JXTG Energy (28), } \\
\text { Toyota (27), Ebara (17), Tokyo } \\
\text { Gas (14), Honda (13), Nippon } \\
\text { Oil Corporation (11), Osaka Gas } \\
\text { (11), Nisshinbo (11), Toyota } \\
\text { Tsusho (11), Toshiba (9), Toho } \\
\text { Gas (8), Sumitomo (7), Idemitsu } \\
\text { Kosan (7), } \\
\text { Panasonic (7), Nissan (7). }\end{array}$ & $\begin{array}{c}\text { JXTG Energy (25), } \\
\text { Iwatani (21), } \\
\text { Toyota (15), } \\
\text { Honda (7), } \\
\text { Toyota Tsusho (7). }\end{array}$ \\
\hline
\end{tabular}


The list of actors and behaviors in the hydrogen energy actor network at each stage is described below (Table 1).

Phase 1-From 1993 to 1999 (Initial stage): The major actors were Ebara and Ballard Generation Systems, who established a joint venture for R\&D of PEFC technology. Most projects by other companies were related to strengthening their existing business.

Phase 2-From 2000 to 2003 (Expansion stage): The major actors were Ebara, Osaka Gas, Toshiba, and Tokyo Gas. These were companies working on household fuel cell technology. Again, most projects by other companies were related to strengthening their existing business.

Phase 3-From 2004 to 2007 (Growth stage): The major actors were Ebara and Nippon Oil Corporation. These were companies working on fuel cell technology. Although new fuel cell technology companies, automakers, and hydrogen suppliers were observed (e.g., Iwatani and Nissan), most projects were again related to strengthening existing business.

Phase 4-From 2008 to 2011 (Decline stage): The major actors were Iwatani, JX TG Energy, Toyota, Honda, Toyota Tsusho, Toho Gas, and Nissan. These companies were automakers, hydrogen producers, and suppliers. Most projects were related to strengthening existing business and newly started FCVs.

Phase 5-From 2012 to 2016 (Re-attention stage): Many actors involved in the decline stage, such as Honda, Toyota Tsusho, and JX TG Energy, were again involved in the re-attention stage. These companies were related to manufacturers of FCVs and hydrogen fuel suppliers. Most projects were focused not only on strengthening existing business, but also on business collaboration and establishment of joint ventures.

\section{Discussion}

As illustrated in the previous section, we can see the different budget allocation strategies for each phase of the NEDO hydrogen program. In the following, we overview the characteristics of each phase and discuss the rationale behind the allocation strategy change. The research projects and specific technology issues at each stage are summarized in Table S2.

In the initial stage the WE-NET project was conducted, which was planned to achieve international use of renewable energy with hydrogen as the energy carrier. Budgetary allocation was centered on the production, storage, and use phases. The importance of establishing a global hydrogen supply chain was emphasized, which was reflected by a balanced budget allocation for production, storage, and use. On the use side, research on hydrogen combustion turbines was conducted. It had a historical background. Basic research on hydrogen combustion was conducted in the Sunshine Project, which was a national research program initiated in 1974 to develop new energy technologies including hydrogen combustion. The hydrogen combustion turbine was considered as the main target of hydrogen utilization in the WE-NET project, rather than fuel cells. However, the main actors on the business side were Ebara and Ballard Generation Systems, who focused on development of PEFC technology. Thus, we can deduce that in the initial stage, NEDO focused on the challenging technology of hydrogen combustion and the global hydrogen supply chain, which were too risky to be invested in only by the private sector.

This balanced budget allocation changed in the expansion stage, where the government started focusing on fuel cells, and budget allocations for fuel cell research increased. Fuel cell projects were adopted as part of the Prime Minister-led Millennium Project [35]. The "Fuel Cell Commercialization Strategy Study Group" was established in METI in 2000 [33]. In 2001, fuel cell technology was assigned as a priority area in the Science and Technology Basic Plan, the sectoral promotion strategy, and the industrial technology strategy of the Japanese government. Corresponding to the movement of the government, R\&D of fuel cell (hydrogen utilization) technology was focused on utilization technologies, and allocations for the same were rapidly increased. Furthermore, the technical development of the fuel cells was not conducted in the WE-NET. As can been seen in Table 1, during this phase the appearance of companies focusing on household fuel cells, including Osaka gas and Toshiba, increased. Contrary to the initial stage, the NEDO strategy and those of the business actors seemed to be synchronized. 
In the growth stage, basic research, such as that on material development, reaction mechanism analysis for the next-generation high-efficiency fuel cell, or improving the durability of the fuel cell at up to stack-system level from cell level, was added as an idea in the "Fuel Cell Commercialization Strategy Study Group" [33]. Thus, the total budget could be increased in the expansion and growth phases. In the expansion and growth stages, Panasonic, Toshiba, and Nippon Oil, which accounted for $90 \%$ of ENE-FARM production, joined the NEDO projects, while Toshiba already appeared in the expansion stage in Table 1 . Therefore, the NEDO projects seemed to each company as strategies for the development of home-use fuel cells. According to the actor change analysis, the major actors were still the manufacturers of PEFC-related products, such as Ebara and Ballard Generation Systems, indicating that the R\&D trend in the industry was also focused on household fuel cells. The governmental commitment to fuel cells during this phase can be confirmed by the technology strategy map published in 2005 and the hydrogen technology development road map published in 2008 [39]. The technical strategy map published in 2005 set fuel cell technologies as important technical solutions in new energy technology for solving global warming such as electrode material, the proton conductor for the PEFC or SOFC, and the hydrogen separation membrane for the extraction of hydrogen [40]. The technical strategy map published in 2007 also identified anode-cathode materials, electrolyte materials, and catalysts for fuel cells as important new energy technologies for solving global warming. However, there were no descriptions of the quantitative targets of performance and cost at that time. In 2008, fuel cell and hydrogen technology development roadmaps were issued for the first time. Although the technology strategy map in 2008 set forward technologies similar to those identified in 2007, this roadmap specified that two types of fuel cells, such as PEFCs and SOFCs, should be focused on and described technical problems in these two fuel cells for stationary applications and FCVs [32]. In addition, this roadmap expressed quantitative targets for performance and cost of fuel cell technology, hydrogen production, storage, and transportation of FCVs.

As can been seen in Figure 1, the total annual budget was halved during the decline stage. A plausible reason for the decline was the shift from R\&D for fuel cells to subsidies for dissemination of ENE-FARM under the budget ceiling. Figure 4 shows the budget allotment of subsidies for purchase of ENE-FARM and the budget for research at NEDO projects related to hydrogen technology, in the decline stage and the re-attention stage. ENE-FARM started sales in 2009 in the decline stage. This was around the time when the total budget of the NEDO projects related to hydrogen technology was reduced. At the same time, subsidies for the purchase of ENE-FARM by METI also started. These actions could have had an impact on the decrease in the total NEDO project budget. However, the total budget for R\&D related to hydrogen technology and subsidies for ENE-FARM were not consistent. Therefore, whether the R\&D budget was converted to the subsidy was still unclear, and we cannot conclude the reason for the decline. From Figure 4, it is evident that the subsidy appeared to contribute to the introduction of ENE-FARM. Subsidies remained at approximately 200 billion yen, or approximately two times the R\&D budget for hydrogen technology, even after 2014. Although beyond the scope of this paper, the duration of the subsidies for ENE-FARM should be discussed in terms of its policy effectiveness for promoting penetration of hydrogen technologies. Interestingly, the main actors changed from the manufacturers of PEFC-related products to automakers, hydrogen producers, and suppliers, indicating that the research and development goals of these companies had changed from household fuel cells in the growth stage to the spread of FCVs in the decline stage.

In the re-attention stage, the supply chain of hydrogen energy was the focus again, as in the initial stage. In the industry, the Council on Competitiveness-Nippon (COCN) proposed the "fuel cell vehicles, hydrogen supply infrastructure spread project" in 2009 [37]. COCN reported that most of the technical barriers to FCV adoption were expected to be resolved by 2015. However, cost challenges and hydrogen supply infrastructure remained major barriers to the spread of FCVs. COCN is a lobby group of the Japanese industry and is influential with the government. The resurgence of an interest in hydrogen supply seemed to be partly because of the COCN report. 


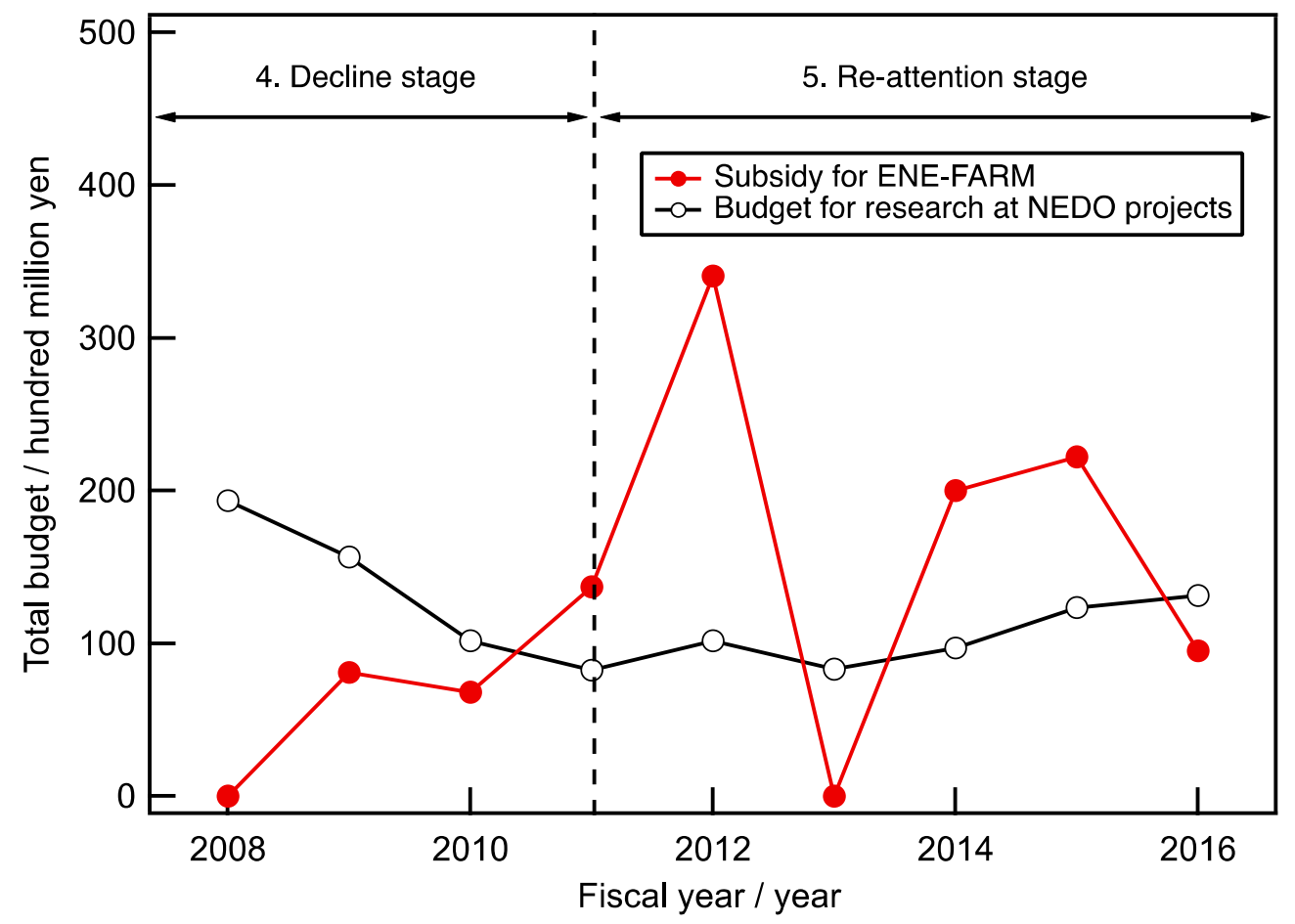

Figure 4. Time-series change in the budget allotment of subsidies for purchase of household fuel cells (ENE-FARM), and the budget for research at NEDO projects related to hydrogen technology, in the decline stage and the re-attention stage.

However, it does not mean that the COCN report immediately changed the direction of the budget allocation of NEDO projects, and we waited, illogically, until 2013, when it was decided that the 2020 Olympic games were to be held in Tokyo. NEDO continued to focus on the technical development of hydrogen utilization, specifically on fuel cells. When it was decided that the 2020 Olympic Games were to take place in Tokyo, the 4th Basic Energy Plan stipulated the construction of the hydrogen supply chain [33]. The Japanese Prime Minister, Mr. Shinzo Abe, mentioned at the hydrogen and other related ministerial conferences in 2015 that the Tokyo Olympic Games would use the hydrogen produced in Fukushima, and that Japan would be a world leader in the development of a hydrogen society [35]. In addition, the Japanese Cabinet Office formed a hydrogen energy system task force for the Tokyo Olympic Games [34]. Thus, the Tokyo Olympic Games could provide the momentum for Japan to become a world leader in hydrogen technology and society. In response to the abovementioned movements, after 2014, NEDO projects invested in research areas related to the hydrogen supply chain, such as hydrogen production, storage, transport, and infrastructure, instead of hydrogen utilization technologies such as fuel cell technologies. Furthermore, the 5th Basic Energy Plan and hydrogen basic strategy were formulated in 2017 and 2018, respectively [41,42]. The 2020 Tokyo Olympics Games were recently postponed because of the COVID-19 pandemic. Although there are a few consequences for $R \& D$ plans caused by the postponement of the Tokyo Olympics Games, there are no public reports and plans related to fuel cell and hydrogen technology, as far as we know. The work on hydrogen society construction toward the 2021 Tokyo Olympics Games could be continued.

In the text above, we investigated the changes in the budget allocation strategy by NEDO and the mechanisms behind these changes. In the initial stage, basic research of each phase of the hydrogen supply chain was conducted by producing and utilizing the hydrogen from the renewable energy power generation. In the expansion and growth phases, the budget allotment changed from hydrogen production to fuel cells, and research related to hydrogen production was discontinued. These movements may have contributed to the production numbers of ENE-FARM. Here, we must note that the supply chains of ENE-FARM and FCV are different. ENE-FARM can utilize existing 
city gas infrastructure and methane reforming. As shown in a paper published in 2008, hydrogen production accounted for over $70 \%$ of the total cost for utilizing hydrogen [43]. To lower these costs, it would be necessary to invest in R\&D of hydrogen production technology. The ENE-FARM was put to practical use in 2009.

Subsequently, the budget allotment gradually shifted to comprehensive technology from utilization technology (fuel cell) in the years following 2014, although the goal of R\&D by these companies could have changed from household fuel cells to FCVs, observed by actor analysis. The target for NEDO projects must have been changed from ENE-FARM to FCVs before the decline stage, and national projects by NEDO had a strong impetus to maintain the allocation. A plausible reason for this lack of allocation change is that, ironically, the technological development of ENE-FARM succeeded, and the subsidies for ENE-FARM continued after the ENE-FARM was put to practical use in 2009. Additionally, there were approximately 48,000 patents related to fuel cell technologies up to 2020 in Japan, as shown in Figure S1, which was more than in the United States $(16,752)$ and China $(16,689)$. Therefore, NEDO research projects contributed to the development of fuel cell technologies and the practical use of ENE-FARM. By contrast, the number of patents relating to hydrogen technologies in Japan remained at 103,853, similar to 90,107 in the US, although China achieved 256,960, as shown in Figure S2. Thus, the contribution of NEDO research projects was not enough to develop hydrogen technologies, such as hydrogen production and transport, storage, and supply. The restart of investment for hydrogen production research had a large time lag of 10 years since its initial stage. Therefore, there could be no $\mathrm{R} \& \mathrm{D}$ or know-how in the companies.

In hindsight, to resolve this issue it was necessary to classify basic and applied research and to adopt different allocation strategies for these two types. Figure 5 shows the change of the budget allotment for hydrogen technology by KAKENHI projects under the Ministry of Education, Culture, Sports, Science and Technology (MEXT), which is another funding resource. The total budget related to hydrogen technology of KAKENHI remained flat, compared to that of NEDO projects under METI. Namely, the bottom-up type of research funds such as KAKENHI's were less susceptible to industrial and political factors, contrary to NEDO projects. Because METI and MEXT are different ministries of the Japanese government, collaborations and orchestrations among different programs might have been difficult but desirable.

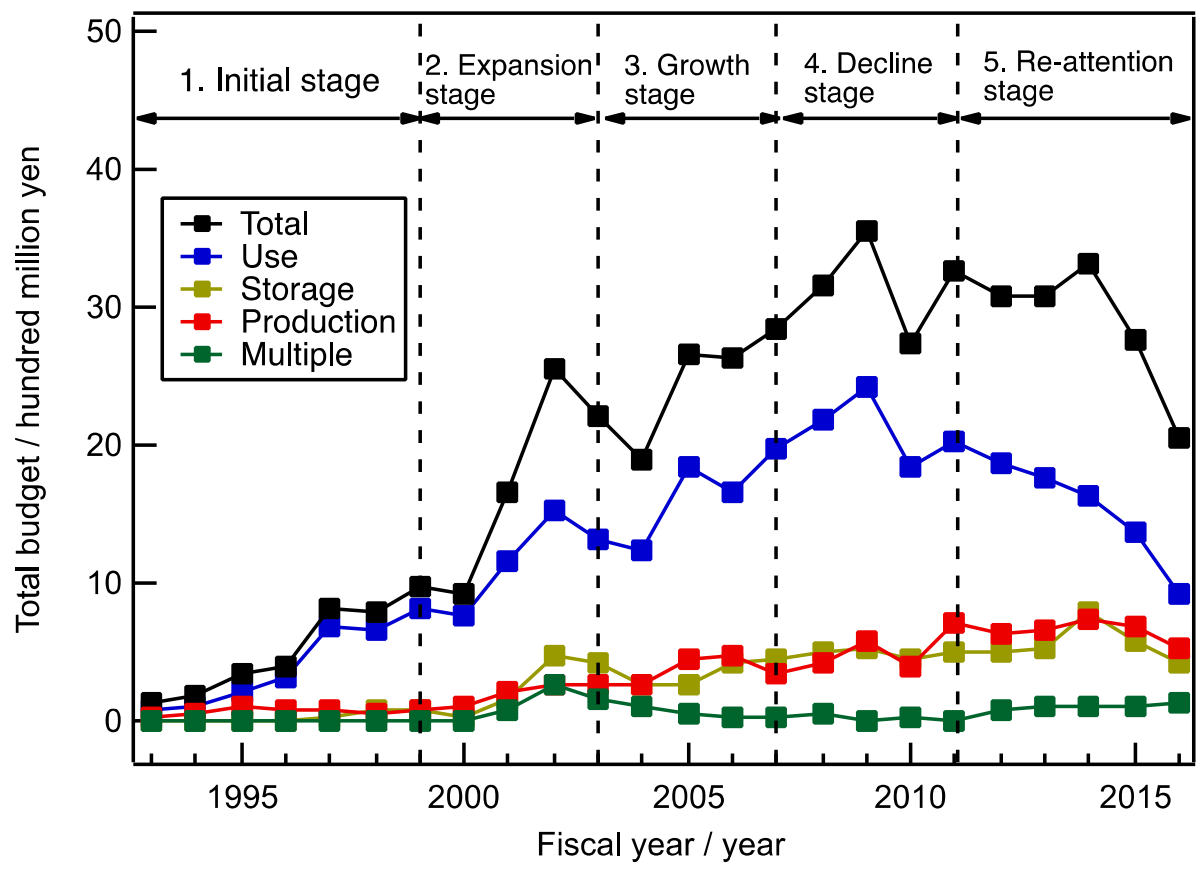

Figure 5. Time-series change in the budget allotment of Grant-in-Aid for Scientific Research database (KAKENHI) grants related to hydrogen technology. 
This study highlights important ways in which the structural inertia hampering the design of national research projects can be alleviated. First, national research projects should be designed in terms of systems thinking. As the first step, we should set the system goals to be achieved, and then design the necessary value chain for achievement. The next step is to break down R\&D plans into stages, instead of relying on the outcome of past research projects. Finally, academic knowledge should be utilized for designing national research projects. The diversity of research fields related to hydrogen technology for KAKENHI was consistently higher than that for NEDO projects (Figure 5). National research projects should be designed based on academic knowledge instead of the lobbying activities of Japanese industrial groups and companies. If these steps are taken, structural inertia for designing national research projects can be alleviated.

\section{Conclusions}

In this study, the transition of budget allocations for hydrogen-related technologies was analyzed by classifying NEDO projects along the two axes of the hydrogen supply chain and the research stage. From 2004 to 2007, the empirical research of fuel cells increased, with most of the research centered on standardization. From 2008 to 2011, investment in basic research on fuel cells increased again, the research on verification of fuel cells was continued, and no allocation for research on hydrogen production was confirmed. After that, the investment trend in terms of the hydrogen supply chain did not change until around 2013, after the practical application of household fuel cells (ENE-FARM) started selling in 2009 and the research trend in industry changed to FCVs. The structural inertia prevented the transition of investments to projects on the hydrogen infrastructure from the hydrogen utilization technology. The NEDO projects should be focused on the hydrogen supply infrastructure when switching from ENE-FARM, using city gas as the existing infrastructure, to FCVs, which require constructing a new hydrogen supply infrastructure, instead of continuing to invest in hydrogen utilization technologies such as fuel cells. This study provides significant implications for designing national research projects without the structural inertia when research goals are changed.

Supplementary Materials: The following are available online at http:/www.mdpi.com/2071-1050/12/20/8546/ s1, Figure S1: Definition of data, Nikkei Information on Firms' Activities (Source: Nikkei Value Search), Table S2: Transitions of specific research and development projects in each stage, Figure S1: The number of patents related to fuel cell technologies each country of applicants (Top 5 in ranking) from 1993 to 2020, Figure S2: The number of patents related to hydrogen technologies each country of applicants (Top 5 in ranking) from 1993 to 2020.

Author Contributions: Conceptualization, K.H., M.T. (Masaharu Tsujimoto) and Y.K.; methodology, K.H., M.T. Masaharu Tsujimoto); validation, K.H., M.T. (Mizutomo Takeuchi); formal analysis, K.H., M.T. (Masaharu Tsujimoto); field investigation, K.H., M.T. (Masaharu Tsujimoto); resources, K.H., M.T. (Masaharu Tsujimoto), Y.K.; data curation, K.H., M.T. (Mizutomo Takeuchi), M.T. (Masaharu Tsujimoto); writing-original draft preparation, K.H.; writing - review and editing, K.H., Y.K.; supervision, Y.K.; project administration, Y.K.; funding acquisition, Y.K. All authors have read and agreed to the published version of the manuscript.

Funding: This research was financially supported by the following project: "Research on description and interpretation of evidence in policy process" (FY2016-FY2019) in the program of Science for Re-designing Science, Technology, and Innovation Policy (SciREX), Research Institute of Science and Technology for Society (RISTEX) of the Japan Science and Technology Agency (JST), and "Comprehensive scenario analysis for prospects and bottleneck of hydrogen energy in future energy system" (FY2016-FY2017) in the program of Advancement of Hydrogen Technologies and Utilization Project, New Energy, and Industrial Technology Development Organization (NEDO).

Acknowledgments: This research was supported by the dual degree program of Tokyo Institute of Technology. We thank Toshiyuki Isshiki at the New Energy, and Industrial Technology Development Organization (NEDO) and Shigeki Iida at the Institute of Applied Energy for their help for investigation such as budget information.

Conflicts of Interest: The authors declare no conflict of interest. The founding sponsors had no role in the design of the study; in the collection, analyses, or interpretation of data; in the writing of the manuscript, and in the decision to publish the results. 


\section{References}

1. The Energy White Paper in 2018. Available online: https://www.enecho.meti.go.jp/about/whitepaper/2018pdf/ (accessed on 7 April 2018).

2. Converse, A.O. The impact of large-scale energy storage requirements on the choice between electricity and hydrogen as the major energy carrier in a non-fossil renewables-only scenario. Energy Policy 2006, 34, 3374-3376. [CrossRef]

3. Adamson, K.-A. Hydrogen from renewable resources-The hundred year commitment. Energy Policy 2004, 32, 1231-1242. [CrossRef]

4. Ehteshami, S.M.M.; Chan, S.H. The role of hydrogen and fuel cells to store renewable energy in the future energy network-Potentials and challenges. Energy Policy 2014, 73, 103-109. [CrossRef]

5. Mejia, C.; Kajikawa, Y. Emerging topics in energy storage based on a large-scale analysis of academic articles and patents. Appl. Energy 2020, 263, 114625. [CrossRef]

6. Balat, M. Potential importance of hydrogen as a future solution to environmental and transportation problems. Int. J. Hydrogen Energy 2008, 33, 4013-4029. [CrossRef]

7. Ball, M.; Wietschel, M. The future of hydrogen-Opportunities and challenges. Int. J. Hydrogen Energy 2009, 34, 615-627. [CrossRef]

8. Hetland, J.; Mulder, G. In search of a sustainable hydrogen economy: How a large-scale transition to hydrogen may affect the primary energy demand and greenhouse gas emissions. Int. J. Hydrogen Energy 2007, 32, 736-747. [CrossRef]

9. Maroufmashat, A.; Fowler, M. Transition of Future Energy System Infrastructure; through Power-to-Gas Pathways. Energies 2017, 10, 1089. [CrossRef]

10. Agnolucci, P.; McDowall, W. Technological change in niches: Auxiliary Power Units and the hydrogen economy. Technol. Forecast. Soc. Chang. 2007, 74, 1394-1410. [CrossRef]

11. Bleischwitz, R.; Bader, N. Policies for the transition towards a hydrogen economy: The EU case. Energy Policy 2010, 38, 5388-5398. [CrossRef]

12. Hisschemöller, M.; Bode, R.; van de Kerkhof, M. What governs the transition to a sustainable hydrogen economy? Articulating the relationship between technologies and political institutions. Energy Policy 2006, 34, 1227-1235. [CrossRef]

13. Lattin, W.C.; Utgikar, V.P. Transition to hydrogen economy in the United States: A 2006 status report. Int. J. Hydrogen Energy 2007, 32, 3230-3237. [CrossRef]

14. Hultman, M.; Yaras, A. The socio-technological history of hydrogen and fuel cells in Sweden 1978-2005; mapping the innovation trajectory. Int. J. Hydrogen Energy 2012, 37, 12043-12053. [CrossRef]

15. Bakker, S. The car industry and the blow-out of the hydrogen hype. Energy Policy 2010, 38, 6540-6544. [CrossRef]

16. Bakker, S.; Van Lente, H.; Meeus, M. Arenas of expectations for hydrogen technologies. Technol. Forecast. Soc. Chang. 2011, 78, 152-162. [CrossRef]

17. Balat, M.; Kirtay, E. Major Technical Barriers to a "Hydrogen Economy". Energy Sources Part A Recovery Util. Environ. Eff. 2010, 32, 863-876. [CrossRef]

18. Cantuarias-Villessuzanne, C.; Weinberger, B.; Roses, L.; Vignes, A.; Brignon, J.-M. Social cost-benefit analysis of hydrogen mobility in Europe. Int. J. Hydrogen Energy 2016, 41, 19304-19311. [CrossRef]

19. Demirbas, A. Future hydrogen economy and policy. Energy Sources Part B Econ. Plan. Policy 2017, 12, $172-181$. [CrossRef]

20. Viktorsson, L.; Heinonen, J.; Skulason, J.; Unnthorsson, R. A Step towards the Hydrogen Economy-A Life Cycle Cost Analysis of A Hydrogen Refueling Station. Energies 2017, 10, 763. [CrossRef]

21. Iribarren, D.; Martín-Gamboa, M.; Manzano, J.; Dufour, J. Assessing the social acceptance of hydrogen for transportation in Spain: An unintentional focus on target population for a potential hydrogen economy. Int. J. Hydrogen Energy 2016, 41, 5203-5208. [CrossRef]

22. Heinz, B.; Graeber, M.; Praktiknjo, A.J. The diffusion process of stationary fuel cells in a two-sided market economy. Energy Policy 2013, 61, 1556-1567. [CrossRef]

23. Lee, D.-H.; Chiu, L.-H. Development of a biohydrogen economy in the United States, China, Japan, and India: With discussion of a chicken-and-egg debate. Int. J. Hydrogen Energy 2012, 37, 15736-15745. [CrossRef] 
24. The Transitions of the Market Dissemination about ENE-FARM. Available online: https://www.gas.or.jp/ user/comfortable-life/enefarm-partners/common/data/20180702_web.pdf (accessed on 14 July 2018).

25. The Statics of the Number of Electric Vehicles in Japan. Available online: http://www.cev-pc.or.jp/tokei/ hanbai.html (accessed on 14 July 2018).

26. Yoshida, T.; Kojima, K. Toyota MIRAI Fuel Cell Vehicle and Progress Toward a Future Hydrogen Society. Electrochem. Soc. Interface 2015, 24, 45-49. [CrossRef]

27. The NEDO Hydrogen Energy White Paper. Available online: https://www.nedo.go.jp/library/suiso_ne_ hakusyo.html (accessed on 7 April 2018).

28. Nakui, K. An Overview of the Fuel Cell and Hydrogen Technology Development Policies in Japan. J. Chem. Eng. Jpn. 2006, 39, 489-502. [CrossRef]

29. Behling, N. Japan's New Plan to Become a Hydrogen Society: Will Japan Succeed? ECS Trans. 2015, 65, 1-23. [CrossRef]

30. Nirasawa, H. Current Status of National SOFC Projects in Japan. ECS Trans. 2017, 78, 33-40. [CrossRef]

31. Behling, N.; Williams, M.C.; Managi, S. Fuel cells and the hydrogen revolution: Analysis of a strategic plan in Japan. Econ. Anal. Policy 2015, 48, 204-221. [CrossRef]

32. The Webpages of the National Research and Development Institute of New Energy and Industrial Technology Development Organization (NEDO). Available online: https://www.nedo.go.jp/ (accessed on 7 April 2018).

33. The Webpage of the Ministry of Economy, Trade and Industry (METI). Available online: https://www.meti. go.jp/english/ (accessed on 7 April 2018).

34. The Webpage of the Japanese Cabinet Office. Available online: https://www.cao.go.jp/index-e.html (accessed on 23 June 2018).

35. The Webpage of the Japanese Prime Minister's Office. Available online: https://japan.kantei.go.jp/ (accessed on 23 June 2018).

36. The Website for the Achieving Project (WARP). Available online: https://warp.ndl.go.jp/?_lang=en (accessed on 7 April 2018).

37. The Webpage of the Council on Competitiveness-Nippon (COCN). Available online: http://www.cocn.jp/ (accessed on 23 June 2018).

38. Database of Grants-in-Aid for Scientific Research (KAKEN). Available online: https://kaken.nii.ac.jp/ja/ (accessed on 23 June 2018).

39. Technical Strategies Maps in 2008. Available online: http://warp.da.ndl.go.jp/info:ndljp/pid/3486530/www. meti.go.jp/policy/economy/gijutsu_kakushin/kenkyu_kaihatu/str2008.html (accessed on 7 April 2018).

40. Technical Strategies Maps in 2005. Available online: http://warp.da.ndl.go.jp/info:ndljp/pid/261351/www. nedo.go.jp/roadmap/2005/index.html (accessed on 7 April 2018).

41. The 5th Basic Energy Plan. Available online: https://www.enecho.meti.go.jp/category/others/basic_plan/pdf/ 180703.pdf (accessed on 14 October 2020).

42. The Basic Hydrogen Strategy. Available online: https:/www.meti.go.jp/press/2017/12/20171226002/ 20171226002-1.pdf (accessed on 14 October 2020).

43. Nakamura, T.; Iwabuchi, H.; Murata, H.; Sakata, K. Supply Cost and Technology Issues of Hydrogen for Fuel Cell Vehicles. Hydrog. Energy Syst. 2008, 33, 27-34.

Publisher's Note: MDPI stays neutral with regard to jurisdictional claims in published maps and institutional affiliations.

(C) 2020 by the authors. Licensee MDPI, Basel, Switzerland. This article is an open access article distributed under the terms and conditions of the Creative Commons Attribution (CC BY) license (http://creativecommons.org/licenses/by/4.0/). 